\title{
Crónica
}

\section{ACTA DE LA COMISIÓN DE PREMIOS AÑO 2007}

En Santiago de Chile, con fecha 7 de Octubre de 2008, a las 17:30 horas, se reúne la Comisión de Premios formada de acuerdo a los artículos 26, 27 y 29 de los Estatutos de la Sociedad Chilena de Obstetricia y Ginecología.

El Jurado constituido por el Presidente de la Sociedad Dr. Eugenio Suárez P. por los Miembros de la Comisión Dr. Pablo Escudero B. y Dr. Enrique Guiloff F., y por el Secretario General, Dr. Hernán Muñoz S., éste último con derecho a voz solamente; acuerdan otorgar los siguientes premios correspondientes al año 2007.

Premio "DR. JORGE DÍAZ BRAVO" año 2007, al mejor trabajo de Ingreso: "PREVALENCIA DE PROCEDIMIENTOS INVASIVOS EN UNA POBLACION CHILENA USUARIA DE METODOS DE CRIBADO Y DIAGNOSTICO PRENATAL" de los Drs. Mauro Parra C., Lorena Quiroz V., Sebastián Pérez B., Carlos Raú M., Rodrigo Terra A., Daniel Pedraza S., Hernán Muñoz S., Enrique Valdés R. Unidad de Medicina Materno-Fetal, Hospital Clínico José Joaquín Aguirre, Facultad de Medicina Universidad de Chile.

Premio "DR. JUAN MALFANTI" año 2007, al mejor trabajo de casuística: Este premio se declaró desierto.

"Mención Honrosa" del premio "Dr. Juan Malfanti" año 2007, al trabajo: "PRONOSTICO NEONATAL DEL RECIEN NACIDO DE MUY BAJO PESO: HOSPITAL REGIONAL DE PUERTO MONTT 2000-2005" de los Drs. José Caro M., Gerardo Flores H. Erika Ortiz F., Carlos Anwandter Sch., Daniel Rodríguez A.

Premio "DR. JUAN WOOD WALTERS" año 2007, al mejor trabajo de Ginecología: "CANCER CERVICOUTERINO ESTADIO III B TRATADO CON RADIOQUIMIOTERAPIA CONCOMITANTE BASADA EN CISPLATINO. EXPERIENCIA INICIAL HOSPITAL CARLOS VAN BUREN de los Drs. José Solis C., Mónica Silva V., Marielisa León P., Guillermo Merino H., Rodrigo Díaz B., Erasmo Bravo O., Christian Franck K., Javier Egaña F. Servicio de Oncología, Hospital Carlos Van Buren, Cátedra de Oncología, Escuela de Medicina, Universidad de Valparaíso, Servicio de Ginecología y Obstetricia, Hospital Carlos Van Buren, Cátedra de Ginecología y Obstetricia Escuela de Medicina, Universidad de Valparaíso.

Mención Honrosa del Premio "Dr. Juan Wood Walters" año 2007, al trabajo: "IMPORTANCIA DE LA CISTOSCOPIA PARA ASEGURAR LA INDEMNIDAD DE LOS URETERES DESPUES DE CIRUGIA VAGINAL" de los Drs. Jack Pardo S., Vicente Solà D., Paolo Ricci A. Enrique Guiloff F. Unidad de Uroginecología y Cirugía Vaginal, Departamento de Ginecología y Obstetricia, Clínica Las Condes.

Premio "DR. VÍCTOR MANUEL GAZITÚA GUZMÁN" año 2007, al mejor trabajo de Obstetricia: Este premio se declaró desierto.

Mención Honrosa del premio "Dr. Víctor Manuel Gacitúa Guzmán” año 2007, al trabajo: "EMBARAZO ECTOPICO: FACTORES DE RIESGO Y CARACTERISTICAS CLINICAS DE LA ENFERMEDAD EN UN GRUPO DE MUJERES CHILENAS" de los autores María Teresa Urrutia S., Lauren Poupin B., Paula Alarcón A., Magdalena Rodríguez C., Loreto Stuven R., del Departamento de Salud de la Mujer, Escuela de Enfermería, Facultad de Medicina, Pontificia Universidad Católica de Chile.

Premio "DR. CARLOS MONCKEBERG BRAVO" año 2007, al mejor trabajo de Perinatología: "RESULTADO NEONATAL ADVERSO EN LA ROTURA PREMATURA DE MEMBRANAS DE PRETERMINO SEGÚN EL MODO DE PARTO" de los Drs. Alfredo Ovalle S., M. Angélica Martinez T., Ariel Fuentes G., Elena Kakarieka W., Carlos Aspillaga M., Ricardo Saavedra M., Sebastian Medel C. del Servicio y Departamento de Obstetricia, Ginecología y neonatología Hospital San Borja Arriarán, facultad de Medicina Universidad de Chile, programa de Microbiología I.C.B.M. Facultad de Medicina Universidad de Chile, Servicio de Anatomía patológica Hospital San Borja Arriarán.

Para dejar constancia firman: Drs. Enrique Guiloff, Pablo Escudero, Hernán Muñoz, Eugenio Suárez. 


\section{How do levonorgestrel-only emergency contraceptive pills (LNG ECPs) prevent pregnancy?}

\section{Levonorgestrel-only emergency contraceptive pills:}

- Inhibit or delay an egg from being released from the ovary when taken before ovulation;

- Possibly prevent the sperm and the egg from meeting by affecting the cervical mucus or the ability of sperm to bind to the egg.

\section{The Evidence:}

\section{Ovulation:}

- A number of studies provide strong direct evidence that LNG ECPs prevent or delay ovulation. If taken before ovulation, LNG ECPs inhibit the pre-ovulatory luteinizing hormone (LH) surge, impeding follicular development and maturation and/or the release of the egg itself. ${ }^{1-7}$ This is the primary and possibly the only mechanism of action for LNG ECPs

\section{Implantation:}

- One study has estimated effectiveness of LNG ECPs by confirming the cycle day by hormonal analysis (other studies used women's self-reported cycle date). In this study, pregnancies occurred only in women who took ECPs on or after the day of ovulation, while no pregnancies occurred in the women who took ECPs before ovulation, providing evidence that ECPs were unable to prevent implantation. ${ }^{8}$

- A number of studies have evaluated whether ECPs produce changes in the histological and biochemical characteristics of the endometrium. Most studies show that LNG ECPs have no such effect on the endometrium, indicating that they have no mechanism to prevent implantation. ${ }^{1,2,9}$ One study found a single altered endometrial parameter only when LNG was administered prior to the LH surge, at a time when ECPs inhibit ovulation..$^{10}$

- One study showed that levonorgestrel did not prevent the attachment of human embryos to a simulated (in vitro) endometrial environment. ${ }^{11}$

- Animal studies demonstrated that LNG ECPs did not prevent implantation of the fertilized egg in the endometrium. ${ }^{12,13}$

\section{Sperm:}

- LNG ECPs may interfere with sperm motility by thickening the cervical mucus, which prevents sperm from reaching the egg, thus inhibiting fertilization. ${ }^{14,15}$ Levonorgestrel may also affect the ability of sperm to bind to an egg. ${ }^{16}$

- However, a recent study did not find any effect of LNG on the number of viable sperm found in the uterine flushings taken 36-60 hours after coitus and 24-48 hours after taking LNG ECPs. ${ }^{17}$

- Research on the effect of LNG ECPs on sperm is inconclusive.

Other facts:

- Emergency contraception is not the same as early medical abortion. EC is effective only in the first few days following intercourse before the ovum is released from the ovary and before the sperm fertilizes the ovum. Medical abortion is an option for women in the early stage of an established pregnancy, but requires a different drug from levonorgestrel.

- EC cannot interrupt an established pregnancy or harm a developing embryo. ${ }^{18,19}$ 


\section{Implications of the research:}

- Inhibition or delay of ovulation is LNG ECP's principal mechanism of action.

- Review of the evidence suggests that LNG ECPs cannot prevent implantation of a fertilized egg. Language on implantation should not be included in LNG ECP product labeling.

- The fact that LNG ECPs have no demonstrated effect on implantation explains why they are not $100 \%$ effective in preventing pregnancy, and are less effective the later they are taken. Women should be given a clear message that ECPs are more effective the sooner they are taken.

- ECPs do not interrupt a pregnancy (by any definition of the beginning of pregnancy). However, ECPs can prevent abortions by reducing unwanted pregnancies.

\section{REFERENCES}

1. Marions L, Hultenby K, Lindell I, Sun X, Stabi B, Gemzell Danielsson K. Emergency contraception with mifepristone and levonorgestrel: mechanism of action. Obstetrics and Gynecology 2002; 100(1): 65-71.

2. Durand M, del Carmen Cravioto M, Raymond EG, Duran-Sanchez O, De la Luz Cruz-Hinojosa M, Castell-Rodriguez A, Schiavon R, Larrea F. On the mechanisms of action of short-term levonorgestrel administration in emergency contraception. Contraception 2001; 64(4):227-234.

3. Hapangama D, Glasier AF, Baird DT. The effects of peri-ovulatory administration of levonorgestrel on the menstrual cycle. Contraception 2001; 63(3): 123-9.

4. Marions L, Cekan SZ, Bygdeman M. Gemzell-Danielsson K. Effect of emergency contraception with levonorgestrel or mifepristone on ovarian function. Contraception 2004; 69: 373-377.

5. Croxatto HB, Brache V, Pavez m, Cochon L, Forcelledo ML, Alvarez F, Massai R, Faundes A, Salvatierra AM. Pituitary-ovarian function following the standard levonorgestrel emergency contraceptive dose or a single $0.75 \mathrm{mg}$ dose given on the days preceding ovulation. Contraception 2004: 70(6):442-450.

6. Okewole IA, Arowojolu AO, Odusoga OL, Oloyede OA, Adeleye OA, Salu J, Dada OA. Effect of single administration of levonorgestrel on the menstrual cycle. Contraception. 2007; 75:372-7

7. Croxatto HB, Devoto L, Durand M, Ezcurra E, Larrea F, Nagle C, Ortiz ME, Vantman D, Vega M, von Hertzen H. Mechanism of action of hormonal preparations used for emergency contraception: a review of the literature. Contraception 2001; 63: 111-121

8. Novikova N, Weisberg E, Stanczyk FZ, Croxatto HB, Fraser IS. Effectiveness of levonorgestrel emergency contraception given before or after ovulation - a pilot study. Contraception 2007: 75: 112-118.

9. Meng CX, Andersson KL, Bentin-Ley U, Gemzell-Danielsson K, Lalitkumar PG. Effect of levonorgestrel and mifepristone on endometrial receptivity markers in a three-dimensional human endometrial cell culture model. Fertility and Sterility 2008 Jan 16 (Epub ahead of print) 10. Durand M, Seppala M, Cravioto M del C, Koistinen H, Koistinen R, Gonzalez-Macedo J, Larrea F. Late follicular phase administration of levonorgestrel as an emergency contraceptive changes the secretory pattern of glycodelin in serum and endometrium during the luteal phase of the menstrual cycle. Contraception 2005; 71: 451-457.

11. Lalitkumar PG, Lalitkumar S, Meng CX, Stavreus-Evers A. Hambiliki F, Bentin-Ley U, Gemzell-Danielsson K. Mifepristone, but not levonorgestrel, inhibits human blastocyst attachment to an in vitro endometrial three-dimensional cell culture model. Human Reproduction 2007; 22(11): 3031-7.

12. Müller A, Llados C, Croxatto HB. Postcoital treatment with levonorgestrel does not disrupt postfertilization events in the rat. Contraception 2003; 67:415-419.

13. Ortiz ME, Ortiz RE, Fuentes A, Parraguez VH, Croxatto HB Post-coital administration of levonorgestrel does not interfere with post-fertilization events in the new world monkey Cebus apella. Human Reproduction 2004; 19(6):1352-1356.

14. Kesseru E, Camacho-Ortega P, Laudahn G, Schopflin G. In vitro action of progestogens on sperm migration in human cervical mucus. Fertility and Sterility $1975 ; 26(1): 57-61$.

15. Kesseru E, Garmendia F, Westphal N, Parada J. The hormonal and peripheral effects of d-norgestrel in postcoital contraception. Contraception 1974; 10(4): 411-24.

16. Munuce MJ; Nascimento JAA; Rosano G; Faundes A; Bahamondes L. Doses of levonorgestrel comparable to that delivered by the levonorgestrelreleasing intrauterine system can modify the in vitro expression of zona binding sites of human spermatozoa Contraception 2006;73:97-101.

17. Do Nascimento JA, Seppalla M, Perdigao A, Espejo-Arce X, Munuce MJ, Hautala L, Koistinen R, Andrade L, Bahamondes L. In vivo assessment of the human sperm acrosome reaction and the expression of glycodeling-A in human endometrium after levonorgestrel-emergency contraceptive pill administration. Human Reproduction 2007; 22(8):2190-5.

18. De Santis M, Cavaliere AF, Straface G, Carducci F, Caruso A. Failure of the emergency contraceptive levonorgestrel and the risk of adverse effects in pregnancy and on fetal development: an observational cohort study. Fertility and Sterility 2005; 84(2):296-9.

19. Bigrigg A, Evans M, Gbolade B, Newton J, Pollard L, Szarewski A, Thomas C, Walling M. Depo Provera: Position paper on clinical use, effectiveness and side effects. British Journal of Family Planning 1999:25(2) 69-76.

\section{ICEC is hosted by Family Care International 588 Broadway Suite 503, NY NY 10012 USA.}

